\title{
GSN Gene
}

National Cancer Institute

\section{Source}

National Cancer Institute. GSN Gene. NCI Thesaurus. Code C150249.

This gene is involved in the regulation of actin filament polymerization. 